Table. Livey dry teight and mitotic activity

\begin{tabular}{|c|c|c|c|c|}
\hline Treatı & $\mathrm{N}$ age & weight & $\mathrm{mg} / 100 \mathrm{~g}$ & mit. $\%$ \\
\hline $\begin{array}{l}x p .1: \text { 1) Saline. . } \\
\text { 2) Homogenate } V \\
\text { t test } p_{1,2} . . . .\end{array}$ & $\begin{array}{ll}6 & 44 \\
4 & 40\end{array}$ & $\begin{array}{l}16 \pm 0.3 \\
18 \pm 0.5\end{array}$ & $\begin{array}{c}856 \pm 15 \\
956 \pm 45 \\
<0.05\end{array}$ & $\begin{array}{l}64 \pm 17 \\
57 \pm 14 \\
>0.05\end{array}$ \\
\hline $\begin{array}{r}x p .2: \text { 1) Saline.. } \\
\text { 2) Homogenate } \mathrm{V} \\
\text { 3) Homogenate } \mathrm{T} \\
\text { t test } p_{1,2} . . . \\
p_{1,3} . .\end{array}$ & $\begin{array}{ll}7 & 80 \\
8 & 77 \\
5 & 80\end{array}$ & $\begin{array}{l}19 \pm 0.3 \\
20 \pm 0.3 \\
20 \pm 0.5\end{array}$ & $\begin{array}{l}699 \pm 9 \\
757 \pm 16 \\
816 \pm 27 \\
<0.02 \\
<0.001\end{array}$ & $\begin{array}{l}123 \pm 8 \\
96 \pm 6 \\
85 \pm 10 \\
<0.02 \\
<0.01\end{array}$ \\
\hline
\end{tabular}

*) Honogenate V: Vir Tis " 45 " homogenizer, $40000 \mathrm{rpm} / \mathrm{min}$ Homogenate T: Thomas $4288 \mathrm{C}$ homogenizer. $1000 \mathrm{rpm} / \mathrm{min}$.

The donors were groups of 4-6 AxC male rats (from Lipschutz, Santiago de Chile, in 1957) about 100 days old and $200 \mathrm{~g}$ of weight. They were killed at 7 p.m. by decapitation and exsanguination. The pituitaries were removed, weighed, pooled and homogenized in aseptic conditions, under ice bath, then diluted with saline solution.

C $3 \mathrm{H} /$ Mza male mice ${ }^{3}$ ) standardized during 20 days $\left.^{4}\right)$ were hepatectomized at noon and injected at 8 p.m. (32 hours after hepatectomy), via intraperitoneum, with saline solution alone or with $0.1 \mathrm{mg}$ of wet pituitary in $0.0125 \mathrm{ml}$ saline per gram of body weight. The mice killed at noon ( 48 hours after hepatectomy), the dry weight $(\mathrm{mg} / 100 \mathrm{~g})$ and mitotic activity (mit. $\%$ ) of the liver were controlled.

The homogenates used raise the dry weight and lower the mitotic activity of regenerating liver. The histologic picture does not suggest that fats and/or carbohydrates are able of raising dry weight.

The opposite effect observed on the two variables could be interpreted as the effect of two different factors in the homogenate or, alternatively, as the effect of a single factor acting on one of the variables, being the variation of the other one, a result of the competitive relations existing between protoplasmic reproduction and cell division 5 ).

UNGAR and HALBERG ${ }^{2}$ ) have described a rise in the adrenal reactivity to $A C T H$, starting in the evening. Bearing this in mind, the time of injection at $8 \mathrm{p} . \mathrm{m}$. could play some role in the appearance of mitotic inhibition, through the liberation of antimitotic glucocorticoids by the pituitary homogenate.

Experiments varying the times of killing the donors and injecting the receivers, according to the time relations of circadian rhythms in pituitary adrenocorticotropic activity already established ${ }^{2}$ ), are now being realized.

We acknowledge the help of Mrs R. Cavoura in performing the hepatectomies and that of Mrs M.A. V. AlborNoz in making the histologic slides. The present work was supported with grants from the Consejo Nacional de Investigaciones Cientificas y Técnicas de la República Argentina and the Liga Mendocina de Lucha contra el Cancer.

Instituto de Patologia General y Experimental, Facultad de Ciencias Médicas, Universidad Nacional de Cuyo, Mendoza, Argentina

$$
\text { J.M. Echave Lianos and J. Russo }
$$

Eingegangen am 10. Februar 1964

1) Weinbren, K.: Gastroenterology 37, 657 (1959). - HARKNESS, R.D.: Brit. Med, Bull. 2, 87 (1957). - 2) UNGAR, F., and F. HAlberG: Experientia 19, 158 (1963). - - 3) Inbred Strains of Mice. Companion Issue to Mouse News Letter No. 29, 55 (1963).${ }^{4}$ ) Halberg, F., C.P. Barnum, R. H. Silber, and J.J. Bittner Proc. Soc. Exptl. Biol. 97, 897 (1958). - 5) Swann, M. M. : Cancer Research 18, 1118 (1958).

\section{Die Rolle der Leber in der Regelung der thyreo-ovarialen Verbindung}

In der Regelung der interhormonalen Verbindungen der Schilddrüse und des Eierstockes gewinnt die Leber eine aktive Rolle. Die Leber baut ab, bindet die Hormone der beiden Drüsen und regelt ihre zirkulierende Menge. Die thyreo-ovariale Korrelation gründet sich auf der gegenseitigen Stimulation und Hernmung. Die Menge der Hormone beeinflußt das Gepräge der Verbindung.

Unsere Versuche fuhrten wir bei vier Tiergruppen durch. Gruppe I: 30 normale Kontrollratten; Gruppe II : 48 thyreoidektomierte und ovariektomierte Tiere; Gruppe III: 46 ovariektomierte Ratten; IV: 50 thyreoidektomierte Ratten. Die
Tabelle. Reakitionszeiten und Prozentsatz der nicht reagierenden Tiere in Abhängigkeit von der Oestrogen-Dosis

\begin{tabular}{|c|c|c|c|c|c|c|c|}
\hline \multicolumn{2}{|c|}{ Oestrogen (Einh.) } & 4 & 8 & 12 & 16 & 20 & 24 \\
\hline $\begin{array}{l}\text { Reaktions- } \\
\text { zeit (Std) }\end{array}$ & $\begin{array}{l}\left.\text { N.K. }{ }^{*}\right) \\
\text { T.O. } \\
\mathrm{O} . \\
\mathrm{T} .\end{array}$ & $\begin{array}{c}26,50 \\
26,25 \\
-\end{array}$ & $\begin{array}{r}36,00 \\
6,00 \\
39,30 \\
7,50\end{array}$ & $\begin{array}{r}41,20 \\
6,00 \\
39,50 \\
16,20\end{array}$ & $\begin{array}{l}52,00 \\
16,80 \\
45,75 \\
26,50\end{array}$ & $\begin{array}{l}79,24 \\
20,00 \\
73,50 \\
37,30\end{array}$ & $\begin{array}{l}87,85 \\
34,10 \\
82,50 \\
48,00\end{array}$ \\
\hline Nicht reag. & T.O.**) & $100 \%$ & $85 \%$ & $60 \%$ & $34 \%$ & $9 \%$ & $0 \%$ \\
\hline Nicht reag. & T. & $100 \%$ & $50 \%$ & $40 \%$ & $28 \%$ & $4 \%$ & $0 \%$ \\
\hline
\end{tabular}
ovariektomierte Gruppe; 0 reoidektomierte Gruppe. — **) \% der nicht reagierenden Tiere in Gruppe T.O. bzw. T.

dritte und vierte Gruppe waren eigentlich nur Kontrollen zu der zweiten Gruppe. Sechs Wochen nach Vornahme der Operationen machten wir stufenförmige Follikelhormonbelastungen. Unsere Ergebnisse zeigt die Tabelle.

Die kleinen und mittelmäßigen Oestrogen-Dosen lösen in den hypothyreotischen und kastrierten Tieren keinen Oestrus aus. Höhere Dosen verursachen auch nur eine vorübergehende Reaktion und auch nur in einem Teil der Tiere. Die thyreoidektomierten Tiere reagieren ähnlich, aber die Reaktionszeit ist länger, und die Zahl der nicht reagierenden Tiere ist niedriger. Die Angaben über die kastrierten Tiere stehen mit denen ïber die Kontrollen in Einklang.

Unsere Versuche beweisen, daß die thyreoidektomierten, kastrierten Ratten keine entsprechende Reaktion auf die Zufuhr des Follikelhormons zeigen. Zu der Auslösung des Oestrus benötigen die Tiere große Dosen, und die $\mathrm{Zahl}$ der nicht reagierenden Tiere ist sehr groß. Die Versuche zeigen ebenso wie unsere Untersuchungen über den Zusammenhang der Lebertätigkeit mit der thyreo-ovarialen Korrelation, daß die Entfernung der Schilddrüse die oestrogenabbauende Fähigkeit der Leber steigert. Wenn wir sowohl Schilddrüse wie Eierstock exstirpieren, so fällt die Hyperfunktion der Leber noch stärker auf, die wir an der gesteigerten Oestrogeninaktivierung gut messen können.

In einem anderen Versuch überzeugten wir uns, daß im Fall der Leberläsion sich die Leberfunktion verbessert, wenn wir die Schilddrüse entfernen ${ }^{1 a}$ ). Also können wir feststellen, daß die Hypothyreose bei gesunder Leber zur funktionellen Hyperaktivität der Leber führt, bei Leberläsion bedeutet also der hypothyreotische Zustand einen Leberschutz. Die bei gesunder Leber sich entwickelnde Hyperfunktion zerstört das hormonale Gleichgewicht des Organismus, indem es $z u$ erhöhtem Abbau der physiologisch sich bildenden und für den Regulationsmechanismus des Organismus notwendigen Hormonmengen führen kann. Es ist anzunehmen, daß solche Zusammenhänge auch eine gewisse Rolle bei der Amenorrhoea der an Myxoedema leidenden Patientinnen spielen. Wenn die Leber geschädigt ist, so ist die normale Schilddrüse im Vergleich mit der kranken Leber als hyperfunktionierende Drüse $z u$ betrachten.

Nach unseren früheren ${ }^{1}$ ) und den jetzigen Versuchen besteht unter gesunden Umständen ein Gleichgewicht zwischen Endokrinium und Leber. Ist die Leber krank, so müssen wir an die Wiederherstellung des Gleichgewichtzustandes denken.

Pharmakologisches Institut (Divehtor: Prof. Dr. T. VÁLxI NAGY) und I. Medizinische Klinik (Direktor: Prof. Dr. B. ForNET) der Medizinischen Universitäi, Debrecen

Judith Kulcsár-Gergely und Andras Kulcsár

Eingegangen am 25. Februar 1964

1) KULCSÁR-GERGELY, J., u. A. KULCSÁr: Naturwissenschaften a) 49,610 (1962); b) 50,693 (1963); c) 51, 43 (1964).

\section{Effect of Coconut Oil on Pre-Established Atheromata in Rabbits}

When rabbits are returned to a normal diet after having been rendered atherosclerotic by cholesterol feeding, there is a sharp fall in serum cholesterol levels, but the atheromata tend to increase in severity ${ }^{1}$. We have recently shown ${ }^{2}$ ) that when fat $(5 \%)$ is added to the normal diet of the rabbits after atheromata have been established, it tends to retard the exacerbation of the severity of the lesions. In that experiment we used two types of fat, one highly unsaturated (iodine number 126) and the other partially unsaturated (iodine number 86). In view of the atherogenicity-enhancing effect of saturated 